\title{
THE TRANSLATION OF ARABIC RELIGIOUS - CULTURAL COLLOCATIONS IN LITERARY TEXTS INTO ENGLISH: AN APPLICATION OF DOMESTICATION AND FOREIGNIZATION TRANSLATION STRATEGIES
}

\author{
Adham Mousa Obeidat ${ }^{1}$ \\ School of Languages, Literacies, and Translation, \\ Universiti Sains Malaysia, 11800 Universiti Sains Malaysia, Penang, Malaysia \\ (Email: adham.translate@gmail.com) \\ Tengku Sepora Tengku Mahadi ${ }^{2}$ \\ School of Languages, Literacies, and Translation, \\ Universiti Sains Malaysia, 11800 Universiti Sains Malaysia, Penang, Malaysia \\ (Email: tsepora@usm.my)
}

Accepted date: $18-06-2019$

Published date: 11-07-2019

To cite this document: Obeidat, A, M., \& Mahadi, T. S. T. (2019). The Translation of Arabic Religious-Cultural Collocations in Literacy Texts into English: An Application of Domestication and Foreignization Translation Strategies. International Journal of Humanities, Philosophy, and Language, 2(6), 155-165.

DOI: $10.35631 / \mathrm{ijhpl} .260013$

Abstract: Since the goal of translation is to bridge the gap between two cultures, translators need to pay attention to literary works. Here lies the importance of good translation to convey cultural messages. The mistranslation of cultural concepts in a literary text may cause misunderstanding of this culture by the TL readers. Therefore, to produce a well-translated literary work, translators need to investigate the expressions that relates to culture such as religious beliefs. The vital role of cultural collocations in a language requires translators to apply effective translation strategies. Domestication and foreignization are two important strategies in translating cultural collocations in a literary text. The authors of this study have applied these strategies to investigate whether religious - cultural collocations in a literary text are domesticated or foreignized. The sentences that have religious - cultural collocations are chosen from an Arabic novel. The collocations are analyzed along with two versions of translation, then the English translations are compared. As a result of discussion, the two translators tend to apply the domestication strategy more frequently. It is found that since religious - cultural collocations are difficult to be understood by the target language readers, the translators tend to reduce their strangeness and domesticate them.

Keywords: Translation, Literary Translation, Collocations, Culture, Domestication and Foreignization Strategies 


\section{Introduction}

Translating a text from one language into another is a complex process since it requires sufficient skills and knowledge of the two languages. On the other hand, this process also needs a wide knowledge of the two cultures to convey figurative and idiomatic expressions, phrases or sentences. Different cultures result in different types of texts. Characteristics of a text could be the same in the two languages. However, they may differ in the semantics and pragmatics dimensions. The variety of text types in languages indicates a variety in the equivalences achieved by the translators. In addition to the procedures and strategies used in the translation process.

Since a literary work is a distinctive text type that aims to reflect a part of a language's culture, the translation of literature, from Arabic into English, plays a vital role to bridge the gap between the two languages. Literary works are among those text that have an influence on readers due to cultural, religious or traditional principals (Shunnaq, 1997, p. 53).

The translator of literary works needs not only to be a bilingual, but also, he/she should have a deep knowledge of the different implications and impacts of the cultural elements used in a literary text. collocations in a literary text are used proficiently to determine the way of using specific lexical items together to express a figurative meaning, traditions, religious beliefs and ideologies of a specific culture. Since collocations are used naturally by the speakers of any language, then they have important functions to make the text more cohesive, to clearly convey the writer's intention and to create new figurative images to the reader.

Thus, translators need to pay more attention to the method of translating collocations to avoid making the collocation looks odd to the receptor readers and to make it more natural expression. However, literal translation succeeds, in some cases, to render the open - ended collocations which has no intended meaning such as بدات الحرب(the war started).

By investigating cultural collocations in a literary work and its translation, the present study aims at applying the strategies of domestication and foreignization on the selected collocations and examining if those collocations are domesticated or foreignized in the target texts. The researchers apply Venuti's (1995) model of domestication and foreignization to examine how collocations, that carry religious beliefs in Arabic culture, can be translated into English. in other words, the objective is to shed light on this type of collocations as an attempt to bridge the gap between the two languages.

\section{Literature Review}

\section{Definition and Importance of Collocations}

Collocations are an important part which have a special value in a literary text. This value cannot be ignored and should be taken into consideration by translators. The importance of this value starts by the vital role of collocations to elaborate how language is used by its speakers and how they help the translators to convey the right message. Their features and characteristics are extraordinary due to the cultural elements and the idiomatic meaning they have. Thus, the employment of collocations in a text changes it from a normal text into a distinctive one.

Collocations in a literary text pose a real challenge for translators as their translation, in most cases, includes problematic issues. A translator will not be able to translate collocations unless 
he / she has a wide knowledge of the two cultures and languages. Moreover, a translator should have a rich cultural and linguistic background of collocations in his own language, and he /she also needs to be aware of the cultural and linguistic features of collocations in the target language. Unqualified translator of the cultural - linguistic features of collocations will result in mistranslate of the collocation, meaning loss, making the target collocations to look odd for readers and losing the beauty of the source literary text. The poor translation will also give a wrong idea or impression about the source culture for the literary text, which goes contrary to the translation function to bridge the gap between cultures.

Accordingly, translators should apply good different translation strategies to manage the various cultural - linguistic features of collocations between the two languages. Cultural implications and intended meaning of collocations should be taken into a special account by the translator. Otherwise, there will be an obvious loss in conveying the beauty cultural image of the source text. Moreover, a translator needs to achieve the main goal of translation of bridging the gap across the two languages and cultures.

The term Collocation refers to the fact of certain words that have the tendency to co-occur regularly with others in a language. It was first introduced by Firth, the introducer of collocations, who believes that the meaning of collocation is completely a lexical meaning (Firth, 1957, p. 195). For him, the lexical meaning is one of five dimensions of meaning (phonetic, lexical, semantic, morphological and syntactic) (p. 196). Oxford Advanced Learner's Dictionary (2005) defines 'collocation' as "a combination of words in a language that happens very often and more frequently than would happen by chance: 'resounding success' and 'crying shame' are English collocations" (p. 293).

"Collocation is that linguistic phenomenon whereby a given vocabulary item prefers the company of another item rather than its 'synonyms' because of constraints which are not on the level of syntax or conceptual meaning, but on that of usage. (Van Roey 1990, p. 46). Baker (1992) contends that some collocations are not difficult to be understood or translated such as open- ended collocations, while some others constitute a challenge to the translator such as marked collocations (p. 55). She defines marked collocations as unusual as they are used out of the collocational ranges to create new images (p. 55). They have a special meaning, figurative images and rhetorical purposes. In the case of literary texts, marked collocations have an important role to make the text more expressive and to make it also more cohesive. Baker (1992) comments that the intended meanings of the marked collocations give them a vital role in the literary texts like fiction, poetry and humor (p. 56). This vital role is because they can create an unusual image, for example, compulsive gambler and heavy gambler. She also asserts the relationship between collocations and culture, by describing collocations as "a direct reflection of the material, social or moral environment in which they occur" (p. 54).

Newmark (1988) discusses the importance of collocations by describing them as the nerves of a text. He states, "if grammar is the bones of a text, collocations are the nerves" (p. 213). Being important to the coherence of a text and carrying idiomatic meaning, collocations are difficult to be understood. They are used in all types of text and used naturally by speakers of a language. Therefore, understanding the meaning and rendering them equivalently is a challengeable task.

Translating collocations starts by recognizing them in the source language (SL) and then rendering them conveniently (Hatim\& Munday, 2004, p. 249). According to Newmark (1988), 
the struggle of translating a collocation starts by (1) recognizing the collocation, (2) the ability of the translator to read the ST collocation as one meaningful unit, (3) finding an appropriate equivalence.

The process of finding the appropriate equivalence of the ST collocations means to launch a process of connecting appropriate nouns with verbs, verbs with nouns, adjectives with nouns and verbs with appropriate adverbial groups (Newmark, 1988, p. 213). Potentially, collocations are either lexical or grammatical. On one hand, the lexical collocations are composed of two or more content words i.e. nouns, verbs, adjectives and adverbs. On the other hand, grammatical collocations refer to the combinations comprising a content word and a function word, which is usually a preposition (Benson, Benson and Ilson, 1997).

Translators adapt many strategies to overlap the problem of translating collocations such as simplification, reduction, synonymy and paraphrasing. Abdullah (2009) states that "the higher the rate of these strategies, the less effective the translation is ... consequently, the less natural the intended communication will be" (p. 4). Although linguists state that the translator should be faithful in translating a collocation, some linguists feel that rendering the ST collocation into a collocation in the TT will result in a collocation which is "unnatural and obscure" (Cowan, 1989, p. 56). However, this kind of unnatural collocation in the TT is sometimes necessary if the target language has no equivalence or if there are no other ways to render it, the unnatural collocation in the TT is a result of a new concept that does not exist in the target language.

\section{Domestication and Foreignization in Translation}

The mentioned translation strategies are developed to most recent strategies suggested by Venuti (1995), which are domestication and foreignization. Venuti (1995) builds his argument of these strategies based on the different methods of translation suggested by Schleiermacher, who believes that "in translation, the translator either leaves the author in peace, as much as possible, and moves the reader towards him, or he leaves the reader in peace and moves the author towards him" (Schleiermacher, 1813, cited in Venuti, 1995, p. 15).

Munday (2001) defines the domestication strategy as a type of translation, where the elements of the source text foreign elements are minimized into the target language values (p. 76). On the other extreme, foreignization is illustrated by keeping the foreign values of the source text in the translated version (Shuttelworth \& Cowie, 1997, p. 59). An example of the difference between the two concepts in the two languages subjects of this study is the collocation, يغض الطرف (Yaghudu al-Tarf) which literary means: ignoring something / someone. To domesticate this collocation into English, a translator may use the procedure of dynamic equivalence and translate it into "turned a blind eye". Any other translation of this collocations, such as literal translation, is foreignization strategy.

Yang (2010) comments that "domestication and foreignization are two basic translation strategies which provide both linguistic and cultural guidance for translator in rendering cultural- specific source texts into parallel target texts" (p. 1). Moreover, Munday (2001) states that "domestication and foreignization come out to answer the question of how to bridge the gulf that had grown between the writer or the source- text which is written in a language that is very culture- bound and the target- text writer" (p. 42). Thus, the debate of these two strategies is not about the linguistic form. They expand beyond the linguistic boundaries to be more concerned with cultures (Sharifabad, Yaqubi \& Mahadi, 2013, p. 96). 
Wang (2014) argues that there is a relation between the literal translation and foreignization strategy as the emphasis is on the linguistic and stylistic features of the original text (p. 2455). Thus, the target text will not be well-coherent and may not be understood by the target readers. Moreover, there is a relation between the free translation and domestication strategy as they both focus on the target culture and target reader. Zinan (1991) states that free translation and domestications produce smother sentences and that sometimes the target reader may not be aware of the fact that they are reading a translated text from another culture (p. 266).

A summary of the studies on domestication and foreignization as translation strategies may lead to the goal of each strategy. Domestication is the strategy that avoiding imposing the SL culture to the target audiences. It helps the translator more to overcome the problem of the linguistic and cultural challenges he/she may faces. Thus, domestication is more communicative strategy that reflects the main aim of translation, which is communication. In this strategy, the reader will have a better understanding of the given text as they are written in their language and culture. Thus, the main target of this strategy is to achieve the dynamic equivalence.

On the other hand, foreignization is the strategy that exposing the TL audiences to the SL culture. This process will reflect in having new concepts for the TL readers. Moreover, it will enrich the TL culture with the various aspects of the SL culture. Thus, the TTs will always have a cultural variety when using this strategy. At the meantime, misusing this strategy by mistranslating the cultural aspects of the SL into the TL will make the translation un-natural for the TL readers. Accordingly, as the main aim of translation is the equivalence; this strategy focuses to achieve the formal equivalence.

Venuti (1995) believes that the domestication strategy is a strategy deals with culture. He divides the steps of this strategy into two main strategies, first, to choose a foreign text or a cultural element of this text, and second, to find and adequate translation method to convey this cultural element into the target text. In this strategy, what is domesticated is the form and content. On contrary, foreignization follows the same steps of the domestication strategy. However, what is foreignized is only the content, while the form is mostly domesticated.

\section{Methodology}

This study is a descriptive one. The researchers find and analyze the Arabic religious - cultural collocations that are mentioned and collected from the Arabic novel "Awlad Hartna", which is written by Naguib Mahfouz. Ten examples are examined along with their two translations in English. The selected examples are related directly to cultural aspects of Arabic culture in general and religious beliefs in particular. The meaning of each ST collocation is studied according to Almaany Dictionary (2018), which provides the meaning of Arabic - Arabic words and phrases by using many Arabic - Arabic dictionaries. The study attempts to examine if Arabic cultural collocations can be translated equivalently into English language. The researchers examine the selected examples according to domestication and foreignization strategies to find out whether the translated collocations are domesticated or foreignized.

\section{Data Analysis}

In this part, the sample of Arabic collocations are analyzed. These 10 examples and their translations are listed in a table along with the strategy used in each version of translation. The Arabic collocations are collected from the Arabic novel "Awlad Hartna". While the English translations are collected from the two versions of the translated novels. The first translated 
novel is called "Children of Gebelawi" by Philip Stewart in 1981. The second translated text is "Children of the Alley" by Peter Theroux in 1988.

The selected Arabic collocations and their translations are analyzed as following:

Table 1. Translation of Collocation in Literary text: Example 1

\begin{tabular}{|c|c|}
\hline Collocation: & وكم دفعني ذللك للطواف ببيته \\
\hline Meaning: & Circumambulation of the Holly House (Ka'aba) \\
\hline $1^{\text {st }}$ Target Text: & Stroll around the tall mansion \\
\hline Strategy: & Domestication \\
\hline $\begin{array}{l}2^{\text {nd }} \text { target Text: } \\
\text { Strategy }\end{array}$ & $\begin{array}{l}\text { Walk around the big house } \\
\text { Domestication }\end{array}$ \\
\hline
\end{tabular}

The two translators fail in conveying the importance of this religious collocation into the target language. The two translated collocations ae domesticated, which results in a loss of the text beauty.

Table 2. Translation of Collocation in Literary text: Example 2

\begin{tabular}{ll} 
Collocation: & \\
\hline Meaning: & Lower the gaze to avoid looking to someone \\
\hline $\mathbf{1}^{\text {st }}$ Target Text: & Looked at the floor \\
\hline Strategy: & Domestication \\
\hline $\begin{array}{l}\mathbf{2}^{\text {nd }} \text { target Text: } \\
\text { Strategy }\end{array}$ & $\begin{array}{l}\text { Lower the gaze } \\
\text { Foreignization }\end{array}$ \\
\hline
\end{tabular}

The first translator is not able to read the collocation as one meaningful unit. Therefore, he tries the best to convey the meaning of the collocation by using the descriptive procedure. The second translator realizes the importance of this collocation in its context and succeeds in finding an equivalent in English.

Table 3. Translation of Collocation in Literary text: Example 3

Collocation:

$$
\text { و اشتتري رزقي بالمنكر والعدوان }
$$

Meaning:

Evil actions and aggression 
$1^{\text {st }}$ Target Text:

Doing harm and making enemies

\begin{tabular}{ll}
\hline Strategy: & Domestication \\
\hline $\mathbf{2}^{\text {nd }}$ target Text: & Doing trouble things and being harmful \\
Strategy & Foreignization \\
\hline
\end{tabular}

The source text collocation is a difficult one since it relates to religious content. The two translators found it as a challenge and translate it by describing the meaning only. The two translators fail to translate it into collocation in the TTs.

Table 4. Translation of Collocation in Literary text: Example 4

\begin{tabular}{ll}
\hline Collocation: & و يشيرون اليه في كل مكان يعيث فيه الفساد \\
\hline Meaning: & Spread corruption and violence \\
\hline $\mathbf{1}^{\text {st }}$ Target Text: & Smashing things up \\
\hline Strategy: & Domestication \\
\hline & \\
\hline $\begin{array}{l}\text { 2nd target Text: } \\
\text { Strategy }\end{array}$ & $\begin{array}{l}\text { Spread corruption } \\
\text { Foreignization }\end{array}$ \\
\hline
\end{tabular}

The first translator finds a difficulty to convey this collocation into a collocation in the target text. However, he succeeds in conveying a partial meaning of it to make it more natural to the target reader. The second translator uses the literal translation procedure to translate this collocation, which results in foreignized it to the target reader and makes it ambiguous as in the source text.

Table 5. Translation of Collocation in Literary text: Example 5

Collocation:

$$
\text { لم يفرض على احد اتاوة ولم يستكبر في الارض }
$$

Meaning:

To behave arrogantly and oppress people

$1^{\text {st }}$ Target Text:

$$
\text { Strut about the world proudly }
$$

Domestication

Strategy:

Behave arrogantly

$2^{\text {nd }}$ target Text: $\quad$ Foreignization

Strategy

This collocation relates directly to Quranic text. Once it is heard by the native speakers of the ST, they will understand the meaning mentioned above. The translators succeed in conveying 
the meaning of this collocation into the target language. However, they use different strategies. The first translator tries to make it easier to the readers by domesticating it, while the second translator translate it literally and uses the foreignization strategy.

Table 6. Translation Of Collocation In Literary Text: Example 6

\begin{tabular}{ll}
\hline Collocation: & ابتعد وهو يلعنه في غيظ مكتوم \\
\hline Meaning: & Repressed anger \\
\hline $\mathbf{1}^{\text {st }}$ Target Text: & Hidden anger \\
\hline Strategy: & Domestication \\
\hline $2^{\text {nd } \text { target Text: }}$ & Silent curse \\
Strategy & Domestication \\
\hline
\end{tabular}

This is another Quranic collocation which is difficult to be translated. The first translator succeeds in conveying the meaning by connecting a target language adjective to a target text noun. However, there is a partial loss of meaning. The second translator fails to read the colocation as one meaningful unit. Therefore, he fails to translate it into a collocation.

Table 7. Translation of Collocation in Literary text: Example 7

\begin{tabular}{|c|c|}
\hline Collocation: & عد الى كوخك واخز الشيطان \\
\hline Meaning: & Don't be possessed by devil \\
\hline $1^{\text {st }}$ Target Text: & The devil has bitten you \\
\hline Strategy: & Domestication \\
\hline $\begin{array}{l}2^{\text {nd }} \text { target Text: } \\
\text { Strategy }\end{array}$ & $\begin{array}{l}\text { Spite the devil } \\
\text { Domestication }\end{array}$ \\
\hline
\end{tabular}

This collocation is deeply rooted to Muslim beliefs and how they try to avoid being possessed by devil. The first translator succeeded in reading this collocation as one meaningful unite, but he fails in finding an equivalent collocation due to the cultural gap between the two languages. The second translator fails in reading this collocation or its function in the source text. Therefore, he also fails in translating it and the target text loses the function of this collocation.

Table 8. Translation of Collocation in Literary text: Example 8

\begin{tabular}{ll}
\hline Collocation: & وبدأ يقر أ بالخط الفارسي: "باسم الله ..... \\
\hline Meaning: & By the name of Allah \\
\hline
\end{tabular}




\begin{tabular}{ll}
\hline $\mathbf{1}^{\text {st }}$ Target Text: & In the name of God \\
\hline Strategy: & Domestication \\
\hline $2^{\text {nd }}$ target Text: & $\begin{array}{l}\text { In the name of God } \\
\text { Strategy }\end{array}$ \\
\hline
\end{tabular}

The word, Allah, in this collocation is very important in the source text as it represents the most common name of God for the source text speakers and readers. The two translators use the same translation by replacing this word by its cultural equivalent in the target text. the two translators use domestication strategy.

Table 9. Translation of Collocation in Literary text: Example 9

\begin{tabular}{ll}
\hline Collocation: & ها قد بدأت صلاة الصبح \\
\hline Meaning: & The dawn prayer for Muslims \\
\hline 1st Target Text: & The dawn prayers \\
\hline Strategy: & Foreignization \\
\hline $\begin{array}{l}\text { 2nd target Text: } \\
\text { Strategy }\end{array}$ & $\begin{array}{l}\text { Morning prayers } \\
\text { Domestication }\end{array}$ \\
\hline
\end{tabular}

This collocation is well known to the native speakers of the source language. The first translator realizes the meaning of this collocation and translated it equivalently by using the foreignization strategy. While the second translator uses the literal translation procedure and domesticates it.

Table 10. Translation of Collocation in Literary text: Example 10

Collocation:

$$
\text { وفتوات تقشعر الابدان عند ذكرهم }
$$

\begin{tabular}{ll}
\hline Meaning: & The skin is shivering because of fear \\
\hline $\mathbf{1}^{\text {st }}$ Target Text: & Make your flesh creep \\
\hline Strategy: & Domestication \\
\hline $\begin{array}{l}\mathbf{2}^{\text {nd }} \text { target Text: } \\
\text { Strategy }\end{array}$ & $\begin{array}{l}\text { Curdle your blood } \\
\text { Domestication }\end{array}$ \\
\hline
\end{tabular}

The two translators succeed in finding equivalences in the target text. the two versions of translation convey the intended meaning of this collocation. However, they don't have the 
same function of beauty of the source text collocation. This Quranic collocation is translated in the Noble Quran as " the skin of the believers' shiver because they fear their God".

\section{Conclusion}

Among the above discussed collocations, the first translator uses the foreignization strategy only one time, while the rest of collocations are domesticated. The second translator uses the foreignization strategy three times, and the other 7 collocations are domesticated. The total of the domesticated collocations is 16 , while foreignization strategy is only used 4 times. Each strategy has its supporters, who believe in its merits and the demerits of the other one. "Domestication designates the type of translation in which a transparent, fluent style is adopted to minimize the strangeness of the foreign text for target language readers, while foreignization means a target text is produced which deliberately breaks target conventions by retaining something of the foreignness of the original" (Shuttleworth \& Cowie 1997, p.59). Venuti (1995) defines domestication as " an ethnocentric reduction of the foreign text to target language culture values, bringing the author back home" (p. 20). He also defines foreignization as "an ethno-deviant pressure on those (cultural) values to register the linguistic and cultural difference of the foreign text, sending the reader abroad" (p. 21). Thus, the domestication the cultural values of a text in the target language will not help in bridging the gap between the two languages. Moreover, domestication strategy ignores the important role of the writer and his / her lexis choice in a particular context.

As a conclusion. It can be said that the argument of using domestication or foreignization strategy has puzzled many translators. However, the successful translator is the one who takes into considerations many factors to have an adequate translation. Both strategies may coexist together in order to conform to the original text and being faithful to the ST. As this paper proved, domestication strategy is a useful strategy to translate religious - cultural collocations from Arabic into English. It could be more applicable strategy to render such phenomenon. However, foreignization strategy is also a useful strategy that may work in some cases. In this point, the translator has the choice to choose between the two strategies in order to be faithful to the St and the translation looks natural to the TL readers. A skilled translator is the one who takes every case of translation as a separated case that needs investigation. Although all the domesticated collocations lose their function in the target language either as a cohesive device, or as a tool to add beautiful figurative images to the text, the meaning is still there whether full meaning or partial meaning. The researchers end with the fact that domestication strategy can be applied to translate religious - cultural collocation. However, they prefer to use the foreignization strategy to keep the beauty of the source text and to convey the source text culture to the target language readers.

\section{References}

Abdullah, Y. Y. (2009). Assessing the Translations of Collocation in the Glorious Quran into English. Adab Al-Rafidyan,57(2010), 724 - 751, 1431st ser.

Baker, M. (1992) In Other Words: A Course book on Translation. London and New York: Routledge.

Baker, M. (2000). Towards a methodology for investigating the style of a literary translator. Target. International Journal of Translation Studies, 12(2), 241266.

Benson, M., Benson, E. \& Ilson, R.(1986).The BBI Combinatory Dictionary of English. Amsterdam and Philadelphia: John Benjamins Publishing Company

Catford, J. C. (1965) A Linguistic Theory of Translation, London: OUP. 
Cowan, L. (1989). Towards a definition of collocation. (Doctoral dissertation), Concordia University, Montreal, Quebec, Canada

Devy.G. (1999). Translation and Literary History. Post-colonial Translation, London: Routledge, 182-88.

Firth, J.R (1957) Papers in Linguistics 1934-1951. London: Oxford University Press.

Gutt, David, T. (1991). Translation and Relevance, Cognition and Context, (Oxford: Basil Blackwell).

Hatim, B. \&Munday, J. (2004). Translation: An advanced resource book. UK: Routledge applied linguistics

Hebron, M. (2004). Mastering the language of literature. Houndmills, Basingstoke, Hampshire; New York: Palgrave Macmillan.

Landers, C. (2001). Literary translation: a practical guide. (Vol. 22), Clevedon: Multilingual Matters.

Munday, J. (2001). Introducing Translation Studies, Theories and Applications, (London,

New York: Routledge).

Newmark, P. (1988). A Textbook of Translation. London: Prentice Hall.

Newmark, P. (2001). Approaches to translation. Shanghai: Sanghai Foreign Language Education Press.

Nida, E. A. (1964). Toward a Science of Translating: with Special Reference to Principals and Procedures Involved in Bible Translating. Leiden: Brill.

Oxford Advanced Learner's Dictionary (2005), 7th edition, Wehmeier, S. (ed.), Oxford: Oxford University Press.

Riffaterre, M. (1992). Transposing Presuppositions on the Semiotics of Literary Translation' in R.Schulte and J.Biguenet (eds.).

Schulte, R. (2001). The Geography of Translation and Interpretation: Traveling Between Languages. U.K: Edwin Mellen Press

Sharifabad, E. D., Yaqubi, M., \& Mahadi, T. S. T. (2013). The Application of Domestication and Foreignization Translation Strategies in English-Persian Translations of News Phrasal Verbs. Theory \& Practice in Language Studies, 3(1).

Shunnaq, A. (1997). Issues in translation: Problems in translating Arabic texts into English. Irbid: Irbid National University \&Jordanian translators' association.

Shuttleworth, M. and Cowie, M. (1997). Dictionary of Translation Studies, Manchester: St. Jerome

Van Roey, J. (1990) : French-English Contrastive Lexicology: An Introduction. Louvainla-Neuve: Peeters

Venuti, L. (1995). The Translator's Invisibility: A History of Translation. London:Routledge.

Wang, F. (2014). An approach to domestication and foreignization from the angle of cultural factors translation. Theory and Practice in Language Studies, 4(11), 2423.

Yang, W. (2010). Brief Study on Domestication and Foreignization in Translation, Journal of Language Teaching and Research, Vol.1, No.1, pp.77-80.

Ye, Zinan. (1991). On Westernized Translation. Chinese Translators Journal, 2, 1518. 